\title{
HEALTH BELIEFS AND STRESS AMONG NON-INSULIN DEPENDENT DIABETES OUT- PATIENTS IN A RURAL TEACHING HOSPITAL IN SOUTH AFRICA
}

\section{Mantwa W Bopape}

Research Officer, Health Behaviour Research Unit, University of the North

\author{
Karl Peltzer \\ Director, Health Behaviour Research Unit, University of the North \\ Corresponding author: peltzerk@mweb.co.za
}

Keywords: Health beliefs; stress; compliance; non-insulin dependent diabetics; rural teaching hospital

\begin{abstract}
The aim of this study was to explore the health beliefs and stress among non-insulin dependent diabetes out patients. The sample included 60 respectively, 20 (33\%) males and 40 (67\%) females within the age range of 41 to 76 (Mean age 61 years, $S D=8.5$ ) from a rural teaching hospital (Mankweng) in Limpopo Province of South Africa. Main outcome measures included the exploratory illness interview schedule, the perception of diabetes mellitus questionnaire and the questionnaire on stress in patients with diabetes-revised. Psychosocial stresses were found to have an important impact on the life of the diabetics. 'Leisure time' was identified as the most important stress factor, followed by physical complications resulting from the disease and the way diabetes affect the relationship with their partners. Most study participants emphasised medical treatment and only used alternative treatments as secondary strategies. A number of diabetic patients suffer from considerable psychosocial stress sometimes associated with poor diabetic control. These patients need psychosocial care incorporating both the patients' family and family background. Health care providers need to consider using different counselling strategies to motivate patients to comply with the treatment regimen and use the self-perception of compliance held by patients to consolidate progress being made by the patient, to enhance self-esteem and further improve overall patient functioning.
\end{abstract}

\section{OPSOMMING}

Die doel van die navorsing was om die oortuigings oor gesondheid en stres van buitepasiënte wat ly aan nieinsulien afhanklike diabetes na te vors. Die steekproef het uit sestig pasiënte van die plattelandse navorsingshospitaal Mankweng in die Limpopo Provinsie in Suid-Afrika bestaan. Van die 60 proefpersone was 20 (33\%) manlik en 40 (67\%) vroulik in die ouderdomsgroep van 41 tot 76 jaar (Gemiddelde ouderdom van 61 jaar en standaardafwyking van 8.5). Die instrumente waarvan gebruik gemaak is, was die volgende: "Exploratory IIIness Review Schedule", "Perception of Diabetes Mellitus Questionnaire" en "The Questionnaire On Stress in patients with Diabetes-revised". Daar is bevind dat psigososiale stressors 'n groot invloed op die lewe van diabete het. Die belangrikste stres faktor was vryetyd. Daarnaas was fisieke komplikasies as gevolg van die siekte en die invloed van die siekte op die verhouding van die pasiënte met hul lewensmaats ook redes vir stres. Die meeste pasiënte het die belangrikheid van die gebruik van medikasie beklemtoon en het alternatiewe medisyne slegs as sekondêre strategie gebruik. 'n Aantal pasiënte het gely aan erge psigososiale stres wat geassosieer word met swak kontrole van diabetes. Hierdie pasiënte benodig psigososiale versorging wat beide die pasiënt se familie en die familie agtergrond insluit. Gesondheidsversorgers behoort verskillende beradingsstrategieë te gebruik om pasiënte te motiveer om behandel te word. Pasiënte se aanvaarding van berading en samewerking is bepalend vir die konsolidering van die pasiënt se vordering, verbeterde selfbeeld en algemene funksionering. 


\section{INTRODUCTION AND PROBLEM STATE- MENT}

The high incidence of diabetes and diabetes related complications continue to be of much concern among health care providers (Zaldivar \& Smolowitz, 1994:303). Managed care organisations in the West are focussing on how health care providers manage their patients with diabetes (Lawler \& Viviani, 1997:369). Adherence to the treatment regimen for patients with diabetes is of major concern to health care providers and of importance for diabetic patients (Schwab, Meyer \& Merrell, 1994:221).

It can be estimated that there are at least one million people with diabetes in South Africa and its prevalence has been found to increase with advancing age as in other regions of the world (Connell, 1991:364).

Interest in monitoring and improving patients' knowledge is essential for patients with chronic diseases like diabetes. Knowledge about different aspects of diabetes management needs to be related to relevant outcomes. The importance of health and perceived control in determining treatment choice and efficacy must be considered when dealing with diabetic patients (Bradley, 1995:99). Many factors contribute to patients' selfmanagement success. The main ones are the attitudes, beliefs or perception of the patients rather than demographic characteristics (Day, 1995:113).

Successful management of diabetes requires attention not just of observable behaviours, but also to the underlying attitudes and belief systems, which drive that behaviour (Greenhalgh, Helman \& Chowdhury, 1998:316). This successful management can be improved by being more patient centred. It is important to consider the patient's goals, values and self-image, i.e. the cognitive contents (beliefs) are expected to be related to compliance (Nurymberg, Kreitler \& Weissler, 1996:26). Research findings indicate that there is a relationship between diabetes and locus of control, i.e. strong beliefs that the patient's behaviour is responsible for the course of the disease (Ulf, Anders \& PerOlof, 1998:15). Konen, Summerson and Dignan (1993:393) state that knowledge of the family function, affect, locus of control, perceived stress, and coping may be useful to the family physician in the care of adults with diabetes mellitus, since these psychoso- cial parameters are associated with objective and perceived glycaemic control.

\section{RESEARCH PROBLEM AND PURPOSE/ AIM OF THE RESEARCH}

Psychological patterns in diabetic patients may manifest themselves in specific ways: patients resist regimens because they want control over their daily activities and living patterns (Lutfey \& Wishner, 1999:635). Two variations in patients' interpretations of diabetes have been found: the extent to which patients primarily oriented themselves toward symptom control or prevention of complications, and their perception of the seriousness of the condition. From the few studies conducted, it has been found that diabetic patients believe diabetes to be a serious condition that could cause complications (Murphy \& Kinmonth, 1995:184).

Diabetes and stress may influence each other directly or indirectly. For example, stress may interfere with regimen adherence and thereby undermine metabolic control. Alternatively, poor control might interfere with general functioning, exacerbating the effects of various stressors to the diabetes regimen (Littlefield, Rodin, Murry \& Craven, 1990:737). Polonsky, Anderson, Lohrer, Welch, Jacobson, Aponte and Schwartz (1995:754) found among female patients with type I and type II diabetes that psychosocial adjustment to diabetes was found to be a unique contributor to adherence to self-care behaviours after adjustment for age, diabetes duration, and general emotional distress.

The non-compliance by diabetic patients is a major problem faced by physicians and health care providers. As many as $50 \%$ of patients seeking treatments, drop out of care within a year. Only $7 \%$ adhere to all of the recommendations considered necessary for proper control of diabetes (Cerkoney \& Hart, 1980:594). Noncompliance and adherence result in serious difficulties to treatment. Non-compliance can be understood in terms of reactance theory (Lutfey \& Wishner, 1999:635): in response to perceived threats to their freedom, and acceptance of chronic disease, patients become motivated to recapture lost freedom by not following medical advice.

Research findings indicate that diabetic patients are less likely to follow medical recommendations espe- 
cially, regarding diet and exercise (Liska, May \& David, 1997:99). It has been found that in Zimbabwe, diabetic patients had not complied with follow-up appointments since more than $60 \%$ lacked comprehension of their disease and the use of medicine prescribed to them. Despite this, there have been few studies on the actual behaviours, beliefs and attitudes of diabetic patients.

Little has been written about diabetic patients' perspectives of their disease. Much of the existing literature has focussed on the psychosocial factors related to diabetes (McCord \& Bradenburg, 1995:267).

The objectives of this study were to assess psychosocial health beliefs and stress of non-insulin dependent diabetes outpatients in a rural teaching hospital in South Africa.

\section{METHODS}

\section{Research design}

This was both a qualitative and quantitative study with a cross-sectional sample.

\section{Sample and procedure}

Participants of this study were 60 Non-Insulin Dependent Diabetes Mellitus (NIDDM) outpatients from Mankweng Hospital.

Permission for the study was obtained from the University of the North ethics committee, the Department of Health and Welfare of the Northern Province, and the Superintendent of Mankweng Hospital. Informal informed consent was gained verbally from participants.

Participants were interviewed and tape-recorded, while they were still waiting to be seen by the doctor.

\section{Data collection and analysis}

During this study, data were collected using interviews and questionnaires.

Interviews were conducted with the exploratory illness interview schedule (Blumhagen, 1982:297) to provide insight into important features of diabetes management and health beliefs. In addition, a set of five open-ended questions was asked, followed by subsequent probing questions if certain questions were answered insufficiently. These questions pertained to the social impact of diabetes, health impact, nutrition practices, exercise habits and health beliefs, and were adopted from Quatromoni, Mibauer, Posner, Carballeira, Bruni and Chipkin (1994:871) in their study to explore the nutrition practices and health beliefs among the Caribbean Latinos with diabetes.

Two questionnaires were used. The Questionnaire on Stress in Patients with Diabetes-Revised (QSP-R) modified and shortened by Herschbacch, Duran, Waadt, Zettler, Amm, Marten-Mitteig and Strain (1997:173) was used to determine if diabetes causes stress and the level of stress, which may lead to noncompliance. It consisted of 45 items describing situations that are sources of stress for many people with diabetes. The items covered the areas of leisure time, work, relationship with partner, doctor-patient relationship, problems with hypoglycaemia, treatment regimen/ diet, physical complications and depression/fear of future. The scores ranged from $0-5$, with the lowest score meaning no stress and the highest, high stress levels. Cronbach alpha as well as split-half reliability coefficients for this scale were .93 and .88 respectively. The Perception of Diabetes Mellitus Questionnaire, developed by Davis, Yarber, Bauserman, Scheer and Davis (1998:178) was used to determine the patients' perceptions and perceived seriousness of the disease and its impact on the patient. It consisted of 35 items about the effect of diabetes mellitus on life, marriage and sexual function. The participants were to respond on a two point scale ' 1 = minimal effect' and ' 2 = great effect'. Cronbach alpha as well as split half reliability coefficient for this scale were .93 and .95 respectively.

Two types of analyses have been performed. Thematic content analysis was applied for the open-ended questions. The statistical procedures for the quantitative analysis included: descriptive statistics and the t-test for the between groups comparisons for closed questions on the semi-structured interviews and questionnaires. The SPSS version 10.0 was used for the statistical analyses. 


\section{RESULTS}

\section{Sample characteristics}

The sample included 60 patients: $20(33 \%)$ were males and $40(67 \%)$ were females. Their ages ranged from 41-76 yrs, with an average age of $61(\mathrm{SD}=8)$. Thirtytwo $(53 \%)$ of the participants were married, $14(23 \%)$ were widowed, 7 (12\%) divorced and 7 (12\%) single. Forty-two percent had secondary education, 24 (40\%) primary education, $4(7 \%)$ tertiary education and 7 (12\%) had never been to school. With regard to their occupational status, 26 (43\%) were retirees, 24 (40\%) unemployed, including house wives and $15(9 \%) \mathrm{em}$ ployed. Twenty-nine (48\%) of them were diagnosed with diabetes for more than 5 years, $20(33 \%)$ for 3 to 5 years and $11(18 \%)$ had been diagnosed for 1 to 3 years. Of the total number of participants, $23(38 \%)$ were both diabetic and hypertensive. Twenty seven $(46 \%)$ of the participants reported to have diabetes related complications diagnosed in their organs, 47 $(61 \%)$ have been diagnosed in eyes, $9(29 \%)$ on feet, $2(6 \%)$ in the urinary bladder or genital areas and 1 $(3 \%)$ have been diagnosed in the nerves.

\section{Causative concepts in diabetes}

Table 1 indicates the causative concepts in diabetes.

Table 1: Frequencies of causative concepts about diabetes

\begin{tabular}{|l|l|l|l|l|}
\hline \multirow{2}{*}{$\begin{array}{l}\text { Causative } \\
\text { concepts }\end{array}$} & \multicolumn{2}{|l|}{ Causes } & \multicolumn{2}{l|}{ Why started } \\
\cline { 2 - 5 } & F & $\%$ & F & $\%$ \\
\hline Eating sugar & 14 & 23 & 8 & 13 \\
\hline Heredity & 6 & 10 & 4 & 8 \\
\hline Problems & 6 & 10 & 6 & 10 \\
\hline Western diet & 6 & 10 & 0 & 0 \\
\hline Fats & 10 & 17 & 6 & 10 \\
\hline Don't know & 18 & 30 & 36 & 60 \\
\hline
\end{tabular}

Most patients (60\%) reported that they did not know why they had diabetes and what caused it. Twenty three percent mentioned that they thought it was caused by eating too much sugar, others mentioned eating too much fats, western diet, heredity and problems (excessive worry).
From qualitative data it was found that most patients $(63 \%)$ had a fatalistic view of the disease with regard to its complications. They mentioned that diabetes is a life long disease. Diabetes was considered inevitable whether it was in the family or not. Religious believes was found to influence some of the patients' causal concepts about the disease. It was believed that personal health is controlled by God, for example "Only God knows why we have this disease." Other patients believed that diabetes is a foreign disease that results from the western diets.

\section{Psychosocial problems associated with diabetes}

Twenty one participants (35\%) reported that they fear blindness, 33\% mentioned fearing diabetes as it is incurable, and $20 \%$ mentioned fearing stroke. Most patients $(95 \%)$ were found to know when their disease was getting better or worse, when their blood glucose was checked at the hospital and when they start to have complications in the body like, feeling dizzy, excessive sweating. If they were getting worse, they $(68 \%)$ reported to adhere strictly to the treatment, especially regarding diet and medication (see Table 2).

Table 2: Frequencies of psychosocial problems associated with diabetes

\begin{tabular}{|c|c|c|c|}
\hline \multicolumn{2}{|c|}{ Nature and Problems Associated with Diabetes } & \multicolumn{2}{|c|}{ TOTALS } \\
\hline & & $\mathrm{F}$ & $\%$ \\
\hline \multirow{3}{*}{$\begin{array}{l}\text { How severe is your } \\
\text { problem? }\end{array}$} & Better & 27 & 45 \\
\hline & Stable & 28 & 47 \\
\hline & Worse & 5 & 8 \\
\hline \multirow[t]{3}{*}{ How long will it last? } & Lifelong & 38 & 63 \\
\hline & God knows & 10 & 17 \\
\hline & Don't know & 12 & 20 \\
\hline \multirow{4}{*}{$\begin{array}{l}\text { What do you fear } \\
\text { most? }\end{array}$} & Blindness & 21 & 35 \\
\hline & Incurable & 20 & 33 \\
\hline & Stroke & 12 & 20 \\
\hline & Nothing & 7 & 12 \\
\hline $\begin{array}{l}\text { Know if the disease } \\
\text { is better or worse }\end{array}$ & Yes & 57 & 95 \\
\hline $\begin{array}{l}\text { How do you know if } \\
\text { disease is worse? }\end{array}$ & $\begin{array}{l}\text { Complications in the } \\
\text { body }\end{array}$ & 30 & 51 \\
\hline \multirow{2}{*}{$\begin{array}{l}\text { If disease is worse, } \\
\text { What do you do? }\end{array}$} & Stick to treatment & 40 & 68 \\
\hline & Go to hospital & 19 & 32 \\
\hline
\end{tabular}


From qualitative interviews it was found that patients complained about bodily complications as a result of diabetes. Complications, which most patients complained of were dizziness, fatigue and exhaustion, disrupted sleep, blurred vision and foot cramps. It was also found that most believed diabetes adversely affects other medical conditions, including high blood pressure. Most patients expressed fears of disabling complications of diabetes such as blindness and stroke.

\section{Management modalities and perceived effectiveness of diabetes treatment}

Table 3 indicates the management modalities and perceived effectiveness of diabetes treatment by the participants.

Table 3: Management modalities and perceived effectiveness of diabetes treatment

\begin{tabular}{|c|c|c|c|c|c|c|c|}
\hline \multirow{2}{*}{\multicolumn{2}{|c|}{$\begin{array}{l}\text { Management Modalities and Perceived } \\
\text { Effectiveness of Treatment }\end{array}$}} & \multicolumn{2}{|c|}{ MALES } & \multicolumn{2}{|c|}{ FEMALES } & \multicolumn{2}{|c|}{ TOTALS } \\
\hline & & \multirow{2}{*}{$\begin{array}{l}\mathrm{F} \\
18\end{array}$} & \multirow{2}{*}{$\begin{array}{l}\% \% \\
90\end{array}$} & \multirow{2}{*}{$\begin{array}{l}\mathrm{F} \\
30\end{array}$} & \multirow{2}{*}{\begin{tabular}{|l|}
$\%$ \\
75
\end{tabular}} & \multirow{2}{*}{\begin{tabular}{|l|}
$F$ \\
48
\end{tabular}} & \multirow{2}{*}{$\begin{array}{l}\% \\
80\end{array}$} \\
\hline Treatment? & Tablets & & & & & & \\
\hline & $\begin{array}{l}\text { Traditional } \\
\text { medicine }\end{array}$ & 2 & 10 & 10 & 25 & 12 & 20 \\
\hline \multirow[t]{3}{*}{ Tablets effective? } & Try & 19 & 95 & 38 & 95 & 57 & 95 \\
\hline & Do well & 0 & 0 & 2 & 5 & 2 & 3 \\
\hline & Not at all & 1 & 5 & 0 & 0 & 1 & 2 \\
\hline \multirow{3}{*}{$\begin{array}{l}\text { Anything that can } \\
\text { help in treating the } \\
\text { problem? }\end{array}$} & Nothing & 20 & 100 & 37 & 92 & 57 & 95 \\
\hline & Home remedies & 0 & 0 & 2 & 5 & 2 & 3 \\
\hline & $\begin{array}{l}\text { Traditional } \\
\text { medicine }\end{array}$ & 0 & 0 & 1 & 2 & 1 & 2 \\
\hline \multirow{2}{*}{$\begin{array}{l}\text { Anyone else who } \\
\text { can help in treating } \\
\text { the problem }\end{array}$} & None & 17 & 85 & 36 & 90 & 53 & 88 \\
\hline & Spiritual healers & 1 & 5 & 2 & 5 & 3 & 5 \\
\hline
\end{tabular}

A considerable number of patients $(80 \%)$ were found to treat their diabetes with medication, which they get from the hospital. This $80 \%$ mentioned that the medications try to control the disease, even if they don't cure it completely. They were also found to believe that no one can control diabetes except for health care professionals. Two percent of the participants was found to use traditional medicines like 'Moshunkwane' (chewed leaves of a tree) especially when they feel dizzy and 'African potato' (root boiled and drank while still hot). Home remedies like 'Lavita' (herbal tea boiled and drank when cool), 'Yarrow' (herbal tea boiled and the vapour inhaled), were also found to be used. Patients mentioned that these home remedies were better than medications as they don't dry the mouth. For example, one patient said "I prefer home remedies, especially Lavita, it is an all purpose remedy, it is better than these medications, it does not keep my mouth dry and feeling thirsty often." Self-monitoring of blood glucose levels was believed to be important in the management of diabetes and avoiding diabetic complications, yet most patients shifted their responsibility to health care professionals.

From the qualitative interviews it was found that the use of traditional and home remedies was not prevalent. A few who reported to have been to traditional healers, faith healers and spiritual healers mentioned that they did not get better instead the disease got worse. They revealed that they did not tell their health care professionals about their use of these traditional and home remedies when they realised that their blood glucose was very high.

\section{Stress factors}

Table $4 \mathrm{a}, 4 \mathrm{~b}$ and $4 \mathrm{c}$ indicate the various stress factors among diabetic patients.

Table 4a: Stress factors (Leisure time) among diabetic patients by frequency and percent

\begin{tabular}{|l|l|l||l|}
\hline Leisure time & $\begin{array}{l}\text { Does not } \\
\text { apply }\end{array}$ & $\begin{array}{l}\text { Slight } \\
\text { problem }\end{array}$ & $\begin{array}{l}\text { Significant } \\
\text { problem }\end{array}$ \\
\cline { 2 - 4 } & Percentages (\%) \\
\hline $\begin{array}{l}\text { 2.I have to plan my free time carefully because } \\
\text { of my diabetes. }\end{array}$ & 28.3 & 26.7 & 45.0 \\
\hline $\begin{array}{l}\text { 16. My diabetes prevents me from spontaneous } \\
\text { physical activities. }\end{array}$ & 36.7 & 23.3 & 40.0 \\
\hline $\begin{array}{l}\text { 18. Travelling has become complicated and } \\
\text { awkward because of my diabetes. }\end{array}$ & 41.7 & 16.7 & 41.7 \\
\hline $\begin{array}{l}\text { 30. Due to my diabetes, I cannot spend my free } \\
\text { time as I wish }\end{array}$ & 45.0 & 11.7 & 43.3 \\
\hline \hline
\end{tabular}

For 'leisure time' all stress items were perceived by more than $40 \%$ of the participants as a significant problem. 
Table 4b: Stress factors (Physical complications) among diabetic patients by frequency and percent

\begin{tabular}{|c|c|c|c|}
\hline \multirow[t]{2}{*}{ Physical complications } & $\begin{array}{l}\text { Does } \\
\text { not } \\
\text { apply }\end{array}$ & $\begin{array}{l}\text { Slight } \\
\text { problem }\end{array}$ & $\begin{array}{l}\text { Significant } \\
\text { problem }\end{array}$ \\
\hline & \multicolumn{3}{|c|}{ Percentages (\%) } \\
\hline 6. I sometimes have gas & 31.7 & 13.3 & 55.0 \\
\hline 17. I suffer from excessive sweating & 46.7 & 18.3 & 35.0 \\
\hline $\begin{array}{l}\text { 19. I suffer from episodes of weakness/lack } \\
\text { of energy }\end{array}$ & 54.2 & 20.3 & 15.4 \\
\hline $\begin{array}{l}\text { 20. I often suffer from physical distress or } \\
\text { discomfort due to my diabetes }\end{array}$ & 47.5 & 18.6 & 33.9 \\
\hline 38. I suffer from pain in my feet & 25.0 & 8.3 & 66.7 \\
\hline 44. I am often thirsty or have a dry mouth & 51.7 & 23.3 & 25.0 \\
\hline
\end{tabular}

Regarding 'physical complications' the two most important stressors were 'I sometimes have gas' and 'I suffer from pain in my feet', which were perceived as a significant problem by $55 \%$ and $66.7 \%$ of the participants, respectively.

Table 4c: Stress factors (Partner) among diabetic patients by frequency and percent

\begin{tabular}{|l||l||l|l||}
\hline Partner & $\begin{array}{l}\text { Does not } \\
\text { apply }\end{array}$ & $\begin{array}{l}\text { Slight } \\
\text { problem }\end{array}$ & $\begin{array}{l}\text { Significant } \\
\text { problem }\end{array}$ \\
\cline { 2 - 4 } & \multicolumn{1}{|l||}{ Percentages (\%) } \\
\hline 3. I am worried about my partner & 35.0 & 8.5 & 36.7 \\
\hline $\begin{array}{l}\text { 14. My physical abilities are limited } \\
\text { because of my diabetes }\end{array}$ & 37.3 & 18.6 & 44.1 \\
\hline $\begin{array}{l}\text { 15. I feel less attractive to others since I } \\
\text { developed diabetes }\end{array}$ & 60.3 & 13.0 & 25.9 \\
\hline $\begin{array}{l}\text { 24. I have had less sex since the onset of } \\
\text { my disease }\end{array}$ & 55.9 & 3.4 & 40.7 \\
\hline $\begin{array}{l}\text { 35. My relationship with my } \\
\text { spouse/partner has become worse } \\
\text { because of my diabetes }\end{array}$ & 55.0 & 5.0 & 40.0 \\
\hline $\begin{array}{l}\text { 43. I often worry about needing } \\
\text { assistance later in life }\end{array}$ & 33.3 & 10.0 & 56.7 \\
\hline
\end{tabular}

For the partner sub-scale, $57 \%$ of the participants perceived 'I often worry about needing assistance later in life' as the major problem. Participants were worried if they will have or still have a partner to assist them in the future.

Table 5 shows the Means and standard deviations of stress subscales in diabetic patients (rated from $0=$ does not apply to $2=$ significant problem).
Table 5: Means and standard deviations of stress subscales in diabetic patients (rated from $0=$ does not apply to 2 = significant problem)

\begin{tabular}{|l|l|l|}
\hline \multirow{2}{*}{ STRESS SUB-SCALES } & \multicolumn{2}{|l|}{ TOTALS (N =60) } \\
\cline { 2 - 3 } & $\mathrm{M}$ & S D \\
\hline 1. Leisure time & 1.00 & .91 \\
\hline 2. Physical complications & .95 & .85 \\
\hline 3. Partner & .84 & .92 \\
\hline 4. Doctor-patient relationship & .69 & .91 \\
\hline 5. Treatment regimen \diet & .67 & .82 \\
\hline 6. Hypoglycaemia & .64 & .81 \\
\hline 7. Work & .57 & .82 \\
\hline
\end{tabular}

The most important stress factors identified were 'leisure time' (1.00), 'physical complications' (.95), and 'partner' (.84). Lower stress ratings were given for 'doctor-patient relationship' (.69), 'treatment and diet' (.67), 'hypoglycaemia' (.64), and 'work' (.57).

Frequency of hypoglycaemic reactions was associated with poor doctor-patient relationship $(r=.31, p<.05)$ but not with any other sources of stress (subscales).

Table 6 indicates the perception of psychosocial stress factors by gender.

Table 6: The perception of psychosocial stress factors by gender

\begin{tabular}{|l|l|l|l|l|l|}
\hline \multirow{2}{*}{ SUB-SCALES } & \multicolumn{2}{l|}{ MALES } & \multicolumn{2}{l|}{ FEMALES } & \multirow{2}{*}{$t$} \\
\cline { 2 - 5 } & $\mathrm{M}$ & SD & $\mathrm{M}$ & $\mathrm{SD}$ & \\
\hline $\begin{array}{l}\text { 1. Life (social life, interests } \\
\text { in life, moods and relying } \\
\text { on others) }\end{array}$ & 35.4 & 5.3 & 33.6 & 5.4 & .022 \\
\hline 2. Marriage & 14.4 & 2.7 & 11.4 & 3.8 & $11.44^{*}$ \\
\hline $\begin{array}{l}\text { 3. Sexual functioning } \\
\text { * } p<.05 .\end{array}$ & 9.4 & 1.6 & 7.7 & 2.6 & $28.39^{*}$ \\
\hline
\end{tabular}

Psychosocial stresses were found to have an important impact on the life of the diabetics. Men believed more than women that diabetes has an influence on marriage and on sexual functioning. From thematic analysis it was also found that many patients believed that diabetes has a strong negative impact on one's social life. It was reported that diabetes makes it difficult for them to participate fully in daily activities varying from household chores to social gatherings. Rea sons mentioned for no longer going to social gatherings were: fear of diabetes-related complications (in front of people), feeling dizzy, fatigue, paining feet, getting hungry and thirsty often. Other reasons men- 
tioned were short temperedness. This was most prevalent for those patients who were both diabetic and hypertensive. These patients (both diabetic and hypertensive) mentioned that they can't get along with people as they take things very seriously and get cross. It was found in this study that diabetics perceived themselves as different from others at social functions involving dining. The other reason mentioned for no longer going to social gatherings was fear of stigmatisation. It was mentioned that people have the tendency of stigmatising and make fun of people with chronic diseases. Activities requiring assistance (cooking food, reading labels on medications, be taken or accompanied to the hospital) contributed to feelings of dependence on others. It was found from this study that the needs of a person with diabetes, particularly dietary needs, were frequently subordinated for the sake of the family.

\section{DISCUSSION}

\section{Causative concepts about diabetes}

From this study, it has been found that most patients don't know the cause of diabetes and why they had it, however, they contributed its cause to food (eating sugar, western diet and fats). Dechamp-Le Roux, Valensi, Assad, Sislian and Attali (1990:211) studied 40 non-obese diabetic patients: 35 IDD and 5 NIDD, who had a knowledge/behaviour gap. Emphasis was placed on the study of their subjective etiological beliefs. Four categories of beliefs were found: stress, heredity, food and drink transgression, and fatality. Stress, which can lead to deresponsibilisation, was the most frequently mentioned etiology (24 patients). Europeans cited several etiological beliefs. North-Africans, in contrast, cited only one, either stress or fatality, but never heredity or food and drink transgression, probably because genetics and genealogy are not superimposable realities and because of their belief in the symbolic benefits of sugar.

\section{Management modalities and perceived ef- fectiveness of diabetes treatment}

Most study participants emphasised medical treatment and only used alternative treatments as secondary strategies. Those patients very actively using alternative approaches also tended to be very actively using biomedical methods. This is similar to the finding by Hunt, Arar and Akana (2000:216) where they interviewed Mexican Americans with type 2 diabetes and found that most actively used biomedical treatments and were less actively involved in alternative approaches. Home remedies/herbs were mentioned as possible alternative treatments for diabetes by $3 \%$ of the study participants and $84 \%$ of the patients in Hunt et al's study. However, most had never or rarely tried herbs and viewed them as supplemental to medical treatments. Most said prayer influences health by reducing stress and bringing healing power to medicines. In this study $20 \%$ used traditional medicine whereas in Hunt's study none used such medicines for diabetes.

Peltzer, Khoza, Lekhuleni, Madu, Cherian and Cherian (2001:42) studied the concepts and treatment for diabetes among traditional and faith healers in the Limpopo Province, South Africa. Their perceived causes of diabetes by both traditional and faith healers could be divided into (1) diet (especially too much of sugar), (2) heredity, (3) supernatural, and (4) psychological causes. Most traditional healers $(92 \%)$ and faith healers $(90 \%)$ indicated that diabetes is curable. Treatments used by the healers in this study included the use of prayer, diet, and herbs.

\section{Stress factors}

Psychosocial stresses were found to have an important impact on the life of the diabetics. 'Leisure time' was identified as the most important stress factor, followed by physical complications resulting from the disease and the way diabetes affect the relationship with their partner. In contrast, in the study by Herschbach et al. (1997:173) 'leisure time' was found to be the second most important stress factor, followed by hypoglycaemia. Depression/fear of future was found to be the first stress factor identified.

Similar to the finding from this study, Samuel-Hodge, Headen, Skelly, Ingram, Keyserling, Jackson, Ammerman and Elasy (2000:928) studied AfricanAmerican women affected by diabetes and found that general life stress and the impact of diabetes manifested in feelings of physical tiredness.

Garay-Sevilla, Malacara, Gonzalez-Contreras, Wrobel- 
Zasada, Wrobel-Kaczmarczyk and Gutierrez-Roa (2000:241) studied the factors associated with perceived psychosocial stress in patients with diabetes mellitus type 2. A stepwise multiple regression analysis showed perceived stress associated with percent body fat and blood glucose while in this study, blood glucose was the second last perceived stress factor.

\section{RECOMMENDATIONS}

Diabetic patients require educational intervention at each stage of adjustment with the disease, and this intervention may be efficient if the current position of adjustment can be accurately determined.

Nurses specifically, should receive more theoretical and practical training to be able to respond appropriately to different emotions exhibited by patients.

Health care providers need to consider using different counselling strategies to motivate patients to comply with the treatment regimen and use the self-perception of compliance held by patients to consolidate progress being made by the patient, enhance self-esteem and further improve overall patient functioning.

As the majority of patients believed they were more active and felt better when they had good glucose control, health care providers might capitalise on this selfperceived progress by gradually recommending even greater lifestyle modifications for control of their diabetes.

\section{CONCLUSION}

A number of diabetic patients suffer from considerable psychosocial stress sometimes associated with poor diabetic control. These patients need psychosocial care incorporating both the patients' family and family background.

\section{REFERENCES}

BLUMHAGEN, D 1982: The Meaning of hypertension. (In: Chrismas, NJ \& Maretzki, TW ed. 1982: Clinically Applied Anthropology. Dordrecht: Kluwer, pp. 297-323.)

BRADLEY, C 1995: Health beliefs and knowledge of patients and doctors in clinical practice and research. Patient- EducationCounselling, 2(1-3):99-106.
CERKONEY, AB \& HART, K 1980: The relationship between the health belief model and compliance of persons with diabetes mellitus. Diabetes Care, 3:594-8.

CONNELL, CM 1991: Psychological context of diabetes and older adulthood: reciprocal effects. The Diabetes Educator, 17(5):364371.

DAVIS, CM; YARBER, WL; BAUSERMAN, R; SCHEER, G \& DAVIS, SL 1998: Handbook of Sexuality-Related Measures. London: Sage.

DAY, JL 1995: Why should patients do what we ask them to do? Patient Education and Counselling, 26(1-3):113-118.

DECHAMP-LE ROUX, C; VALENSI, P; ASSAD, N; SISLIAN, P \& ATTALI, JR 1990: Beliefs in diabetics about the etiology of their disease. Influence of ethnicity. Diabete Metabolisme 16(3):20712.

GARAY-SEVILLA, ME; MALACARA, JM; GONZALEZCONTRERAS, E; WROBEL-ZASADA, K; WROBELKACZMARCZYK, K \& GUTIERREZ-ROA, A 2000: Perceived psychological stress in diabetes mellitus type 2. Revister Investigasion Clinica, 52(3):241-5.

GREENEHALGH, T; HELMAN, C \& CHOWDHURY, AM 1998: Health beliefs and folk models of diabetes in British Bangladeshis: a qualitative study. British Medical Journal, 316(7136):978-983. HERSCHBACCH, P; DURAN, G; WAADT, S; ZETTLER, A; AMM, C; MARTEN-MITTEIG, B \& STRAIN, F 1997: Psychometric properties of the questionnaire on stress in patients with diabetes-revised (QSD-R). Health Psychology, 16(2):171-174.

HUNT, LM; ARAR, NH \& AKANA, LL 2000: Herbs, prayer, and insulin. Use of medical and alternative treatments by a group of Mexican American diabetes patients. Journal of Family Practice 49(3):216-23.

KONEN, JC; SUMMERSON, JH \& DIGNAN, MB 1993: Family function, stress, and locus of control. Relationships to glycemia in adults with diabetes mellitus. Archives of Family Medicine 2(4):393402.

LAWLER, FH \& VIVIANI, N 1997: Patients and physicians' perspectives regarding treatment of diabetes: compliance with practice guidelines. The Journal of Family Practice, 44(4):369-375. LISKA, BA; MAY, LW \& DAVID, C 1997: Medical self care compliance with recommended treatment regimens among chronically ill middle-aged and Elderly Persons. Research in the Sociologyof-Health-Care, 14:99-117.

LITTLEFIELD, CH; RODIN, GM; MURRY, MA \& CRAVEN, JL 1990: Influence of functional Impairment and social support on depressive symptoms in persons with diabetes. Health Psychology, 9(6):37-49.

LUTFEY, KE \& WISHNER, WJ 1999: Beyond compliance is adherence: improving prospects of diabetes care. Journal of Clinical and Applied Research and Education: Diabetes Care, 
22(3):635-39.

MCCORD, EC \& BRANDENBURG, C 1995: Beliefs and attitudes of persons with diabetes. Family Practice, 27(4):67-71.

MURPHY, E \& KINMONTH, AL 1995: No symptoms no problem? Patients' understanding of non insulin dependent diabetes. Family

Practice, 12(2):184-192.

NURYMBERG, K; KREITLER, S \& WEISSLER, K 1996: The cognitive orientation of compliance in short and long term Type II diabetic patients. Patient Education and Counselling, 29(1):2539.

PELTZER, K; KHOZA, LB; LEKHULENI, ME; MADU, SN; CHERIAN, VI \& CHERIAN, L 2001: Concepts and treatment of diabetes by traditional and faith healers in the Northern Province, South Africa. Curationis, 24(2):42-47.

POLONSKY, WH; ANDERSON, BJ; LOHRER, PA; WELCH, G; JACOBSON, AM; APONTE, JE \& SCHWARTZ, CE 1995: Assessment of diabetes-related distress. Diabetes Care 18(6):754-60. QUATROMONI, PA; MIBAUER, M; POSNER, BM; CARBALLEIRA, NP; BRUNI, M \& CHIPKIN, SR 1994: Use of focus groups to explore nutrition practices and health beliefs of urban Caribbean Latinos with diabetes. Diabetes Educator, 17(8):69-873.

SAMUEL-HODGE, CD; HEADEN, SW; SKELLY, AH; INGRAM, AF; KEYSERLING, TC; JACKSON, EJ; AMMERMAN, AS \& ELASY, TA 2000: Influences on day-to-day self-management of type 2 diabetes among African-American women: spirituality, the multicaregiver role, and other social context factors. Diabetes Care, 23(7):928-33

SCHWAB, T; MEYER, J \& MERELL, R 1994: Measuring attitudes and health beliefs among Mexican Americans with diabetes. Diabetes- Education, 20(3):221-7.

ULF, S; ANDERS, W \& PER-OLOF, R 1998: Relationship between locus of control, beliefs and metabolic control in insulin dependent diabetes mellitus. British Journal of Health Psychology, 1:1525.

ZALDIVAR, A \& SMOLOWITZ, J 1994: Perception of the importance placed on religion and folk medicine by non-Mexican-American Hispanic adults with diabetes. Diabetes-Education, 20(4):303-306. 